\title{
Isolation and Characterization of Ralstonia solanacearum causing Bacterial Wilt of Potato in Konkan Region of Maharashtra
}

\author{
U. R. Phondekar, R.G. Bhagwat, R.R. Rathod*, Amruta D. Gadhave, \\ Y.R. Nirgude, Revati R. Nalawade and Josiya Joy \\ Department of Plant Pathology, College of Agriculture, DBSKKV, Dapoli, India \\ *Corresponding author
}

\section{A B S T R A C T}

\section{Ke yw ords \\ Bacterial wilt, Potato, Isolation, Characterization, Ralstonia solanacearum \\ Article Info \\ Accepted: \\ 04 September 2020 Available Online: 10 October 2020}

The isolation of $R$. solanacearum was carried out by streak plate method on TZC agar medium from bacterial wilted potato plant. The $R$. solanacearum was identified on the basis of different Morpho-biochemical characteristics. The colonies of test bacterium were appeared as, dull white or creamy colour, irregularly round fluidal colonies and opaque with light pink or red center on TZC agar medium. The $R$. solanacearum was Gram negative in reaction and positive for $\mathrm{KOH}$ solubility, acid production, starch hydrolysis, catalase test, production of hydrogen sulphide, Motility test and Casein hydrolysis test.

\section{Introduction}

The Potato (Solanum tuberosum L.) belonging to family Solanaceae is a vitally important starchy food crop of the world, commonly known as the "Poor Man's Friend". Potato is the staple food in many parts of the world and is an important part of the world's food supply. The potato crop is infested by many bacterial, fungal, viral, viroidal, nematodal diseases, etc. Bacterial wilt disease is responsible for yield loss in potato upto $70 \%$, in India (Staff, 2018). Bacterial wilt or brown rot is caused by the pathogenic bacterium Ralstonia solanacearum (Smith) Yabuuchi. The disease pathogen has extensively been distributed in tropical, subtropical and some warm temperate regions of the world and is one of the major constraints in the production of potato crop.

$R$. solanacearum, is a rod shaped, gram negative, non-spore forming $\beta$ proteobacterium and its size ranges from 0.5 - 0.7 x $1.5-2.0 \mu \mathrm{m}$, which causes bacterial wilt in more than 200 plant species of many economically important crops. It survives for longer period in soil, water, latently infected plants and can be spread by soil, water, farm equipments and infected plant materials (Hayward, 1991). The bacterial wilt of potato 
was noted and reported in India from Pune district of Maharashtra (Cappel, 1892) (Fig. $1)$. Keeping these facts in mind, the present study focusing on bacterial wilt disease of potato was carried out at the Department of Plant Pathology, College of Agriculture, Dapoli.

\section{Materials and Methods \\ Collection of disease samples}

The potato plants showing typical symptoms of bacterial wilt were identified and such diseased samples were collected from wilt infested field of Central Experiment Station, Wakawali. Diseased plants were uprooted and kept in polythene bags and brought to the laboratory for isolation and further studies.

\section{Stem streaming test}

The test was conducted by placing a cut section of stem in test tube containing sterilized water. Within few minutes, viscous white spontaneous slime stream of bacterial cells exuded from cut end of the stem into sterilized water, which was the indication of presence of bacterium in infected stem tissue.

\section{Isolation of the pathogen ( $R$. solanacearum)}

Isolation of the test bacterium was done by following streak plate method on Triphenyltetrazolium Chloride (TZC) agar medium. The infected plant tissue which was found positive in oozing was subjected for isolation. The surface sterilized stem pieces placed in test tube containing $10 \mathrm{ml}$ sterile distilled water for 10-15 min.

The inoculation loop was dipped in test tube containing bacterial ooze and then streaked on petriplates containing TZC agar medium. Inoculated plates were incubated at $28 \pm 2{ }^{\circ} \mathrm{C}$ for 24 to 48 hours to observe bacterial colonies.

\section{Pathogenicity test}

Pathogenicity test were carried out by soil drenching and seed dipping method. The potato seed tubers of Cv. Kufri pukhraj was obtained from Central Experiment Station, Wakavali were used for conducting pathogenicity test.

\section{Soil drenching method}

Potato seed tubers were sown in pots containing sterilized potting mixture, soil + sand + FYM (2:1:1). The bacterial suspension was prepared from 72 hours old bacterial culture on TZC medium and poured around the root zone of 30 days old potato plants. The uninoculated pot served as a control.

\section{Seed dipping method}

The potato seed tubers were surface sterilized with $95 \%$ ethanol and then washed with sterile distilled water to remove traces of chemical. Then seed tubers of potato were soaked in $72 \mathrm{hrs}$ old bacterial suspension for one hour. Then soaked tubers were sown in plastic pots containing sterilized potting mixture, soil + sand + FYM (2:1:1).

\section{Characterization of the pathogen $(R$.} solanacearum)

Different Morpho-biochemical tests were carried out to characterize the $R$. solanacearum are described below.

\section{Gram staining}

Gram staining test was performed as per standard method.

\section{KOH solubility test}

A clean glass slide was inoculated with a loop of $48 \mathrm{hrs}$ old bacterial culture. Few drops of $3 \% \mathrm{KOH}$ (Potassium hydroxide) were added 
on the clean glass slide containing bacterial culture and mixed thoroughly for 5-10 seconds with the help of bacterial inoculation needle for formation of slime threads.

\section{Acid production}

Nutrient broth containing 2 per cent glucose (adjusted to $\mathrm{pH} 7.0$ ) was prepared and $48 \mathrm{hrs}$ old bacterial culture was inoculated in the test tubes containing nutrient broth. The inoculated test tubes were kept for incubation for 7 days at $28 \pm 2^{0} \mathrm{C}$. After incubation, few drops methyl red indicator was added in the test tubes. A discrete red or pink colour indicates the positive reaction.

\section{Starch hydrolysis}

48 hrs old bacterial culture inoculated on petriplates containing sterilized starch agar medium and incubated for $96 \mathrm{hrs}$ at $28 \pm 2{ }^{0} \mathrm{C}$. Then incubated plates were flooded with lugol's iodine solution. The clear zone around the bacterial growth indicates a positive reaction.

\section{Production of Hydrogen sulphide $\left(\mathrm{H}_{2} \mathrm{~S}\right)$}

A nutrient broth with additional 3\% peptone was prepared and poured into test tube. The test tubes were sterilized in autoclave and inoculated with $48 \mathrm{hrs}$ old bacterial culture. Then, filter paper strips were soaked in super saturated solution of lead acetate and were kept for drying. After drying, they were inserted into test tubes with cotton plug. The inoculated tubes were incubated for seven days at $28 \pm 2^{\circ} \mathrm{C}$. Filter paper strips turns into black colour indicates positive reaction.

\section{Catalase test}

On a clean glass slide add a loopful bacterial culture from a test tube containing $48 \mathrm{hrs}$ old of test pathogen. Few drops of $3 \%$ hydrogen peroxide $\left(\mathrm{H}_{2} \mathrm{O}_{2}\right)$ was added on clean glass slide, and mixed with the help of bacterial inoculation needle.

\section{Motility test}

The test bacterium culture from 48 hrs old was streaked on petriplates containing motility agar medium with the help of sterile bacterial inoculation needle and inoculated plates were incubated for two days at $28 \pm$ $2^{0} \mathrm{C}$.

\section{Casein hydrolysis}

A loopful of 48 hours old bacterial culture was streaked on petriplates containing sterilized skim milk agar medium and plates were incubated in an inverted position for two days at $28 \pm 2{ }^{\circ} \mathrm{C}$.

\section{Results and Discussion}

\section{Isolation}

The virulent colonies of test bacterium developed on TZC agar medium appeared as, dull white or creamy colour, irregularly round fluidal colonies and opaque with light pink or red center and non virulent colonies appeared dark red in colour (Fig. 2). This result is similar with the report of Dhital et al., (2001), Ahmed et al., (2013) and Chamedjeu et al., (2018) isolated $R$. solanacearum on TZC medium from infected potato plants.

\section{Pathogenicity test}

The symptoms observed on inoculated potato plants by both methods as, tender leaves lost their turgidity, lower leaves pale yellowing, drooping of infected leaves, the leaves became flaccid and sudden wilting of the whole plant (Fig. 3). This result is conformity with Shweta et al., 2018 who proved pathogenicity of $R$. solanacearum by soil 
drenching method for potato.

\section{Characterization}

The results of gram staining revealed that test bacterium was gram negative; rod shaped and retained reddish pink coloured cells (Table 1 and Fig. 4). Several workers like Pawaskar et al., (2014), Singh et al., (2015) and Bannihatti, R.K. (2015) reported similar results of gram staining. The bacterium formed slime threads (Fig. 4) when 48 hrs old bacterial culture was mixed with $3 \% \mathrm{KOH}$ solution and showed positive reaction for test (Table 1). This result is similar with the report of Rahman et al., (2010), Chakravarty and Kalita (2011) and Singh et al., (2015) reported $R$. solanacearum to be positive in $\mathrm{KOH}$ solubility test.

Table.1 Morpho-biochemical characterization of $R$. solanacearum

\begin{tabular}{|l|l|l|}
\hline Sr. No. & Tests & Reaction \\
\hline 1. & Gram staining & Gram negative \\
\hline 2. & KOH solubility & Positive \\
\hline 3. & Acid production & Positive \\
\hline 4. & Starch hydrolysis & Positive \\
\hline 5. & Catalase test & Positive \\
\hline 6. & Production of H2S & Positive \\
\hline 7. & Motility test & Positive \\
\hline 8. & Casein hydrolysis & Positive \\
\hline
\end{tabular}

Fig.1 Typical symptoms of $R$. solanacearum on potato tubers
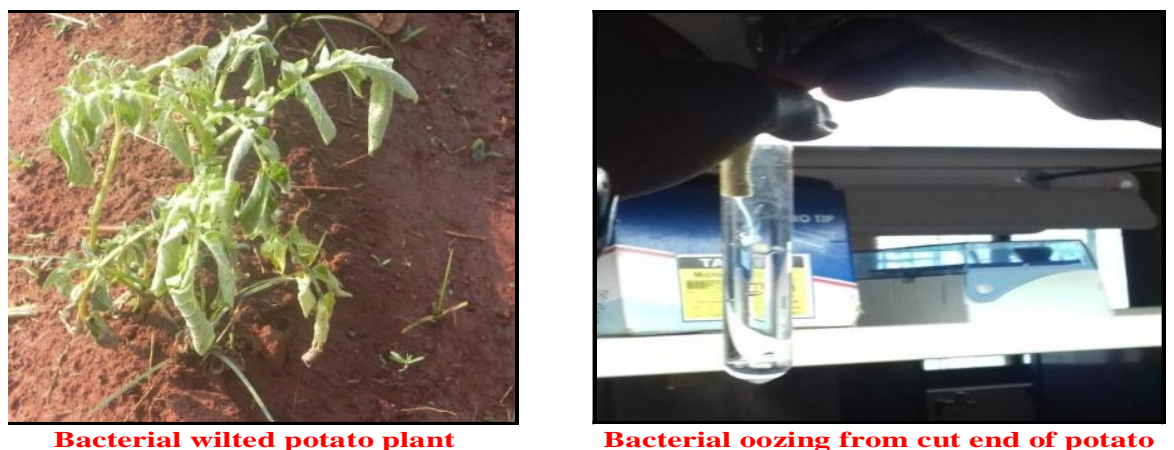

Bacterial oozing from cut end of potato

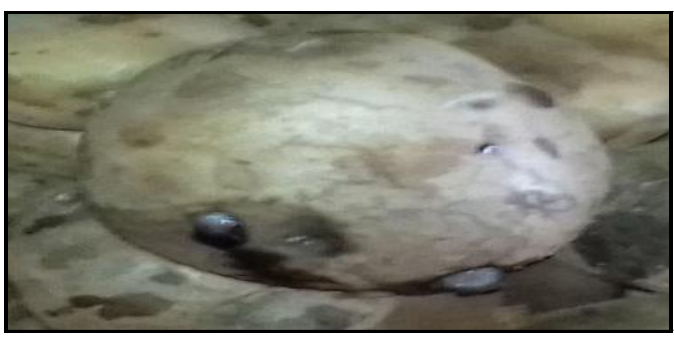

Bacterial oozing from infected tuber eye 
Fig.2 Colonies of $R$. solanacearum on TZC/ CPG medium

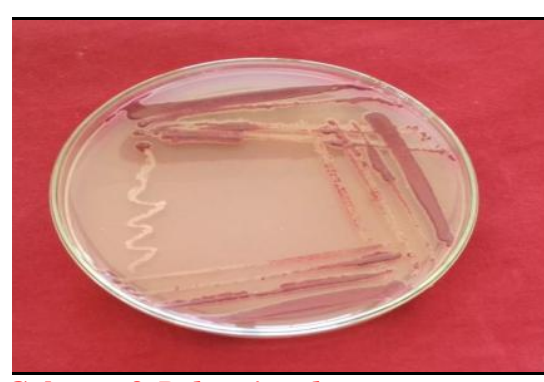

Culture of Ralstonia solanacearum on TZC medium

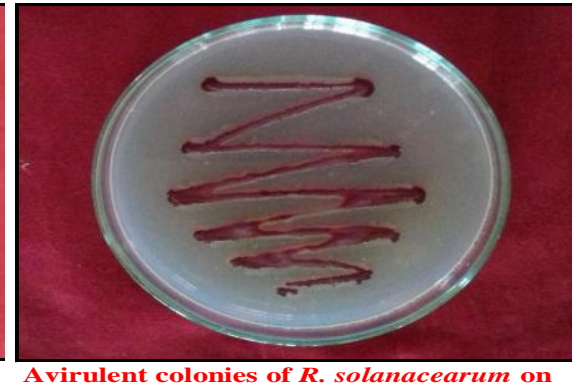

TZC medium

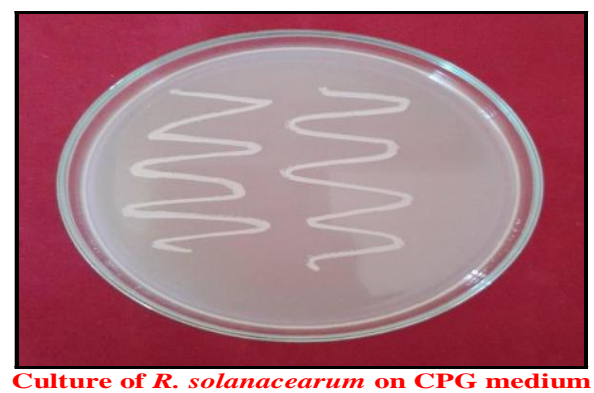

Fig.3 Pathogenicity test of $R$. solanacearum on potato

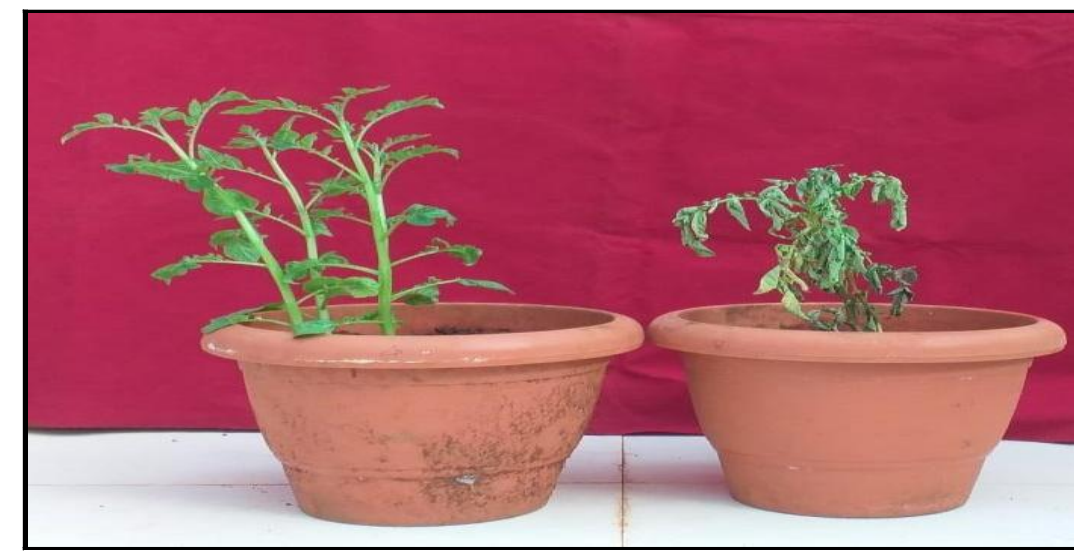

Soil drenching method

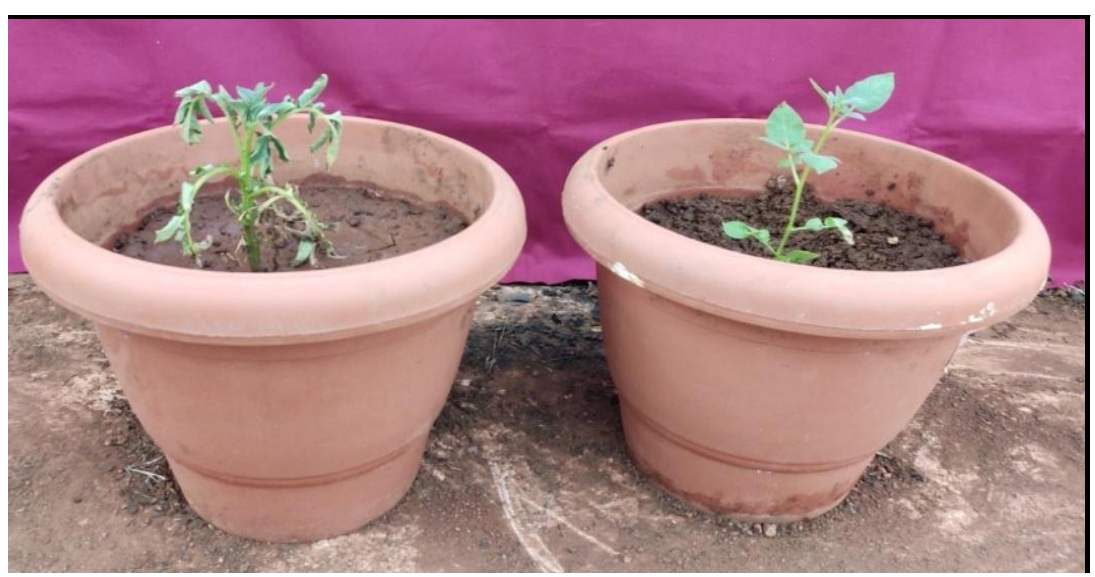


Fig.4 Morpho-Biochemical characterization of $R$. solanacearum

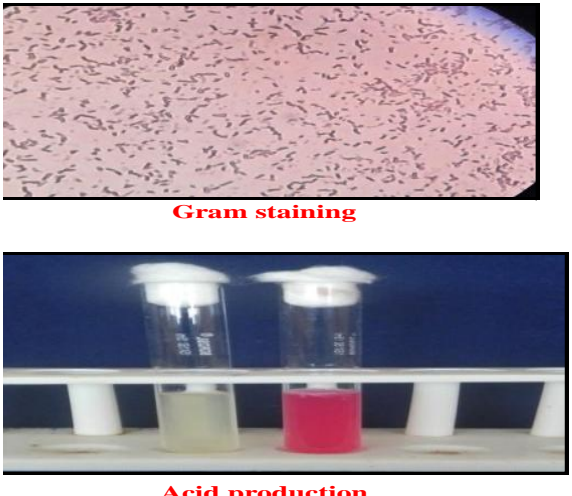

Acid production

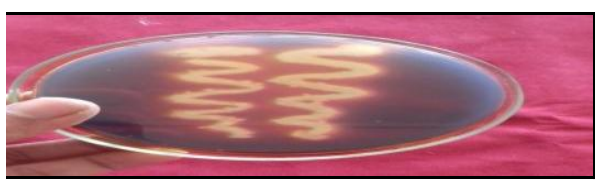

Starch Hydrolysis

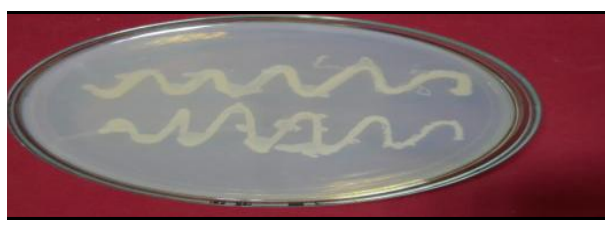

Motility test

The bacterium produced acid (Fig. 4) when grown on nutrient broth containing 2 per cent glucose after addition of methyl red indicator and hence, showed positive reaction (Table.1) for test. Pawaskar et al., (2014) reported similar results of Acid production test.

The bacterium was able to hydrolyse starch and formed clear zone (Fig. 4) around the bacterial colony growth on starch agar medium when flooded with lugol's iodine which indicated positive reaction (Table.1). This result is similar with the report of Bannihatti, R. K. (2015), Kataky et al., (2017) and Salvi et al., (2020) reported $R$. solanacearum to be positive in starch hydrolysis test.

Formation of gas bubbles (Fig. 4) indicated positive reaction for catalase test (Table.1). Gas bubbles formation revealed the presence of aerobic and facultative anaerobic bacteria. Bannihatti, R. K. (2015) reported similar results of catalase test.

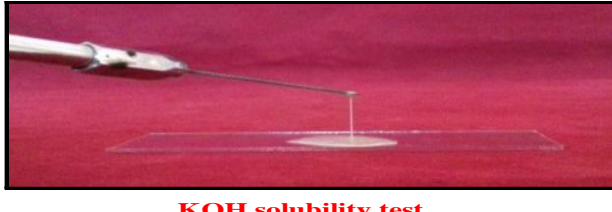

KOH solubility test

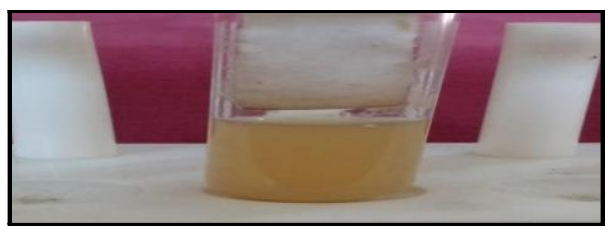

Production of Hydrogen Sulphide

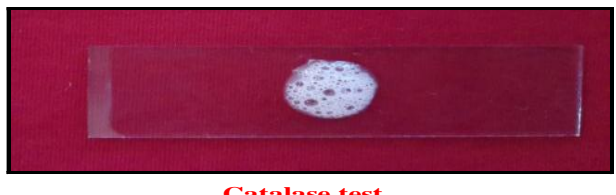

Catalase test

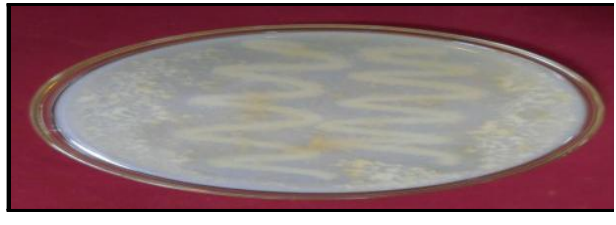

Casein hydrolysis

The bacterium was able to produce Hydrogen sulphide and blackening of filter paper strips (Fig. 4) indicated positive reaction for test (Table.1). Salvi et al., (2020) reported similar results of Production of Hydrogen sulphide test.

The bacterium formed spreading colony (Fig. 4) when grown on motility agar medium, it after 48 hrs of incubation, hence bacterium showed positive reaction for test (Table.1). Bannihatti, R. K. (2015) reported similar results of motility test.

The bacterium formed clear zone around the bacterial growth (Fig. 4) when grown on skim milk agar medium, and bacterium showed positive reaction for test (Table.1). Bannihatti, R. K. (2015) reported similar results of casein hydrolysis test.

From the results (Table. 1) it was concluded that the bacterium $R$. solanacearum was Gram negative in reaction. The bacterium showed positive reaction to all biochemical tests viz., 
$\mathrm{KOH}$ solubility test, acid production test, starch hydrolysis, catalase test, production of hydrogen sulphide, motility test and casein hydrolysis test.

\section{References}

Ahmed, N.N., Islam, M.R., Hossain, M.A., Meah, M.B. and Hossain, M.M., 2013. Determination of races and biovars of Ralstonia solanacearum causing bacterial wilt disease of potato. J. Agric. Sci. 5 (6): 247-251.

Bannihatti, R.K., 2015. Studies on bacterial wilt of tomato caused by Ralstonia solanacearum (Smith) Yabuuchi. M.Sc. (Agri) Thesis, VNMKV, Parbhani.

Cappel, E.L., 1982. A note on potato disease prevalent in Poona district and elsewhere. Rep. Dept. Ld. Rec. Agric. Bombay.16.

Chamedjeu, R.R., Masanga, J., Matiru, V. and Runo, S., 2018. Isolation and characterization of Ralstonia solanacearum strains causing bacterial wilt of potato in Nakuru County of Kenya. African. J. Biotech. 17 (52): 1455-1465.

Dhital, S.P., Thaveechai, N.and Shrestha, S.K., 2001. Characteristics of Ralstonia solanacearum strains of Potato wilt disease from Nepal and Thailand. Nepal Agric. Res. J. 4 \& 5: 42-47.

Hayward, A.C., 1991. Biology and epidemiology of bacterial wilt caused by Pseudomonas solanacearum. Annu. Rev. Phytopathol. 29: 65- 87.

Kataky, M., Tamuli, A.K., Teron, R. and Sarma, R.K., 2017. Biochemical characterization of Ralstonia solanacerum, causing bacterial wilt of brinjal in The Hilly District of Assam. Internat. J. Pure Appl. Biosci. 5 (4): 2147-2157.

Pawaskar, J., Joshi, M.S., Navathe, S. and Agale, R.C., 2014. Physiological and biochemical characters of Ralstonia solanacearum. Internat. J. Res. Agric. Sci. 1 (6):2348 -3997.

Rahman, M.F., Islam, M.R., Rahman, T. and Meah, M.B., 2010. Biochemical characterization of Ralstonia solanacerum causing bacterial wilt of brinjal in Bangladesh. Prog. Agric. 21(1 \& 2): $9-19$.

Salvi, P.P., Borkar, P.G., Kadam, J.J. and Solanki, M.S., 2020. Physiological and biochemical characterization of Ralstonia solanacearum inciting bacterial wilt of brinjal. Int. J. Chem. Studies 8 (2): 397-401.

Shweta, H.M., Prasanna Kumar, M.K., Teli, K., Kunduru, B. and Chandra Shekar, B.S., 2018. Isolation, identification and molecular characterization of Ralstonia solanacerum isolates collected from Southern Karnataka. J. Appl. Nat. Sci. 10(3): $886-893$.

Singh, R.., Jagtap G.P., Jatwa, T.K. and Bannihatti, R.K., 2015. Cultural and biochemical characterization of Ralstonia solanacearum causing bacterial wilt in Ginger. Progres. Res. Internat. J. 10 (Special-IV): 2346-2349.

Staff, K. J., 2018. Major diseases of Potato, https://krishijagran.com/news/majordiseases-of potato.

\section{How to cite this article:}

Phondekar, U. R., R.G. Bhagwat, R.R. Rathod, Amruta D. Gadhave, Y.R. Nirgude, Revati R. Nalawade and Josiya Joy. 2020. Isolation and Characterization of Ralstonia solanacearum causing Bacterial Wilt of Potato in Konkan Region of Maharashtra. Int.J.Curr.Microbiol.App.Sci. 9(10): 136-142. doi: https://doi.org/10.20546/ijcmas.2020.910.018 